\title{
Analyses of Genetic Variability, Character Association, Heritability and Genetic Advance of Tossa Jute (Corchorus olitorius) Genotypes for Morphology \& Stem Anatomy
}

\author{
Mukul Md. Mia*, Nargis Akter, Md. Golam Mostofa, Sheikh Shorif Uddin Ahmed, Iffat Jahan Nur, \\ Md. Al-Mamun, Md. Harun-Or Rashid
}

Breeding Division, Bangladesh Jute Research Institute, Manik Mia Avenue, Dhaka, Bangladesh

\section{Email address:}

mukulbjribreeding@gmail.com (M. Md. Mia),drnargisbjri@gmail.com (N. Akter), chistyagric@gmail.com (S. S. U. Ahmed), mostofabjri@gmail.com (Md. G. Mostofa),iffat.jessica@yahoo.com (I. J. Nur), almamunbjri@gmail.com (Md. Al-Mamun), harunbjri@yahoo.com (Md. Harun-Or R.)

${ }^{*}$ Corresponding author

\section{To cite this article:}

Mukul Md. Mia, Nargis Akter, Md. Golam Mostofa, Sheikh Shorif Uddin Ahmed, Iffat Jahan Nur, Md. Al-Mamun, Md. Harun-Or Rashid. Analyses of Genetic Variability, Character Association, Heritability and Genetic Advance of Tossa Jute (Corchorus olitorius) Genotypes for Morphology \& Stem Anatomy. American Journal of BioScience. Vol. 8, No. 4, 2020, pp. 99-112. doi: 10.11648/j.ajbio.20200804.12

Received: June 9, 2020; Accepted: June 20, 2020; Published: July 13, 2020

\begin{abstract}
Background and aims: Investigation was carried out to estimate the variability, heritability, genetic advance for fiber yield based on yield attributing morpho-anatomical traits of tossa jute in field and laboratory. Materials \& Methods: The experiments were carried out using 12 tossa jute genotypes followed by randomized complete block design in five jute research regions (Rangpur, Faridpur, Jessore, Manikganj districts and Bangladesh Jute Research Institute head office, Dhaka) of Bangladesh during 2019-20. Hypothesis: The tested genotypes were expected to perform better for fiber yield than control varieties. Results: The jute genotypes i.e. Acc. 1318, Acc. 1306, (JRO S 1 ), O-412-9-4, O-0512-6-2 providing good results for plant height, base diameter, green weight and dry fiber yield in morphological study; and total trapezoidal area per transverse section, number of trapezoid per T. section, bark diameter, bark thickness in anatomical study depicting the more variability as well as possibility of tossa jute development. These morphological and anatomical traits showing significant association with one another, and coupled with high genetic and phenotypic variance-covariance components; high heritability; high \& moderate genetic advance and genetic advance in percent of mean would be used for selection of jute genotypes regarding the jute crop improvement for fiber yield. Conclusions: The high variation for morphological and anatomical characters may be considered as effective method for screening of jute genotypes for higher fiber yield comparing with control varieties. The genotypes i.e. Acc. 1318, Acc. 1306, (JRO S $)$, O-412-9-4, O-0512-6-2 with good morphological and anatomical traits related to yield could be used as parents in breeding program as well as jute variety development.
\end{abstract}

Keywords: Genetic Advance, Gene Bank, Genotypic-Phenotypic Correlation, Heritability, Phloem Fiber, Jute Anatomy

\section{Introduction}

Bangladesh Jute Research Institute was established in 1951 with the mandate to complete research on both agricultural and industrial aspects on jute and allied fiber crops right from sowing seeds to preparing the products in the industries for its various uses at the end users level [1]. Jute is a fiber crop belongs to the genus Corchorus of the Tiliaceae family with two cultivated species namely,
Corchorus capsularis L. and Corchorus olitorius L. bearing chromosome number $2 n=2 x=14$ yield jute, which is a secondary phloem fiber obtained from the bark of the stem [2, 3]. Corchorus is a genus of about $40-100$ species of flowering plants in the family Tiliaceae, native to tropical and subtropical regions throughout the world [57]. It is widely known for its high genetic diversity and 
geographical distribution and C. olitorius is from Africa [4].

The origin and phylogeny of the genus Corchorus as a whole or its two domesticated species (C. capsularis L. and C. olitorius L.) has long been controversial [58]. The white jute $(C$. capsularis $\mathrm{L}$.) was originated from Indo-Myanmar region including south China [4], and the dark jute $(C$. capsularis L.) from Africa [3].

Crop improvement programs on Jute allow for selection of varieties with finer and high-quality fiber gained considerable attention over the years in China, Bangladesh, and India [5]. Jute is considered as the second most important fibrous plant throughout the world [6]. In the trade, C. olitorius L. is known as "Tossa Jute". It is a 'Golden Fiber' of Bangladesh contributing about 4\% GDP to the national economy and earns about $5 \%$ of the foreign exchange as well [1]. The jute fiber quality for textile and other products depends on various characters [7]. Maity et al. [8] reported that, jute fiber is used mostly for making Gunny bags and Packaging materials for agricultural and industrial products. The cultivated species of jute are globally important for fiber yield and their wild species are potential source for abiotic and biotic stress tolerant genes as well as important genetic resources. Interspecific hybridization between wild and cultivated species may lead to conserve the wild germplasms and to create genetic diversity in jute plants [9].

Genetic improvement of the cultivars of jute (Corchorus olitorius L. and Corchorus capsularis L.) is needed to broaden the genetic base of new cultivars. The two species indeed are distantly related and their maternal origins may be different. On the contrary, genetic variability present at the intraspecific level is low [10].

Islam and Rahman [11] opined that, jute plants are harvested from the field at maturity stage normally 100 (early) or 120 (quietly late) days after sowing for fiber production purpose. Harvested Jute plants are made into bundles and then steeped under water of ponds, ditches, canals, lakes, rivers etc. as available in layers for retting. Water-hyacinth, water weeds, stems of banana plants, mango logs, earth chunks, bamboo etc. are used for submerging under water. In about 15-20 days, the retting is completed and then fibers are extracted manually, washed and dried for sale. Since retting is the most important and predominant of all the factors influencing the fiber quality, Bangladesh Jute Research Institute has evolved many location specific improved Jute retting technologies. There is a great economic significance of fiber quality. In fact, in the context of present situation in which a severe competition between Jute and synthetic fibers is going on in respect of fineness, strength and price, the future of Jute fiber is very greatly depending on its quality. Jute will never be able to win this competition unless its quality is greatly improved and ensured the grade-wise price for the farmers.

The exploitation of existing diversity of each individual accession by using phenotypic traits is an initial step towards crop improvement. Nwangburuka and Denton [12] reported significant differences among fifteen tossa jute genotypes in terms of morphological traits viz. plant height at maturity, number of leaves per plant, fresh leaf weight, stem weight, total plant weight and harvest index. It is so essential for the breeders to gather deep knowledge on the genetic diversity and variability as well as genetic architecture for fiber yield and yield components of jute germplasm for improving fiber yield content in jute plant [13]. To study the anatomical features of jute plant, destructive sampling is required to be done prior to seed production [14].

Correlations between jute fiber quality and other attributing anatomical characters are helpful to improve desired characters as well as to select good germplasm for breeding purpose [15]. However, a few attempts have been made to link anatomical characters with fiber yield and such results are genotype specific [16]. In hybridization technique, a breeder relies on indirect estimation of fiber yield considering plant height and plant base diameter, green weight with leaves and without leaves, dry fiber yield and dry stick yield of the jute plant. The heritability and correlation of these characters have been found to be variable depending on environmental conditions, retting methods and management practices. It is important to develop new high yielding and good quality varieties of jute to meet the expanding demand of jute fiber. Therefore, tossa jute genotypes were evaluated for fiber yield and quality based on morpho-anatomical traits and to examine fiber development patterns through nondestructive sampling.

\section{Materials and Methods}

\subsection{Location}

The experiment was conducted as partly in the field of Jute

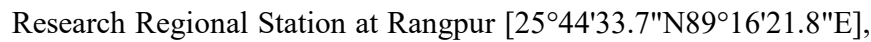
Faridpur $\quad\left[23^{\circ} 35^{\prime} 23.2^{\prime \prime} \mathrm{N} \quad 89^{\circ} 48^{\prime} 43.1 " \mathrm{E}\right], \quad$ Manirampur-Jessore

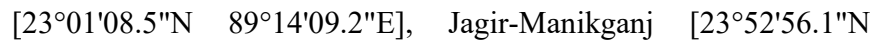
90 01'53.0"E] Districts and Bangladesh Jute Research Institute (BJRI), Manik Mia Avenue $\left(23^{\circ} 45^{\prime} 26^{\prime \prime} \mathrm{N}, 90^{\circ} 22^{\prime} 47^{\prime \prime} \mathrm{E}\right)$, Dhaka, Bangladesh during 2019 to 2020 [17]. The anatomical works were done in the laboratory of the breeding division of BJRI, Dhaka.

\subsection{Plant Materials}

Twelve tossa jute genotypes were used in this experiment (Table 1). The accession materials of unknown characters were collected from the gene bank of BJRI and studied for phenotypic diversity [18]. The experiment was laid out in randomized complete block design with three replications [19]. 
Table 1. List of plant materials with their identifying characters, plant type and source of collection.

\begin{tabular}{|c|c|c|c|c|}
\hline SL. & Genotype & Identifying characters & Plant type & Source \\
\hline 1 & $\mathrm{G}_{1}=$ Acc. 1306 & Full green plant, ovate lanceolate leaf & \multirow{3}{*}{ Accession } & Gene Bank, \\
\hline 2 & $\mathrm{G}_{2}=$ Acc. 1318 & Full green plant, ovate lanceolate leaf & & BJRI \\
\hline 3 & $\mathrm{G}_{3}=\mathrm{O}-0512-6-2$ & Full green plant, lanceolate leaf & & \multirow{6}{*}{$\begin{array}{l}\text { Breeding } \\
\text { Division, } \\
\text { BJRI }\end{array}$} \\
\hline 4 & $\mathrm{G}_{4}=\mathrm{O}-0412-9-4$ & Stem \& leaf stipule red, ovate lanceolate leaf & \multirow{5}{*}{$\begin{array}{l}\text { True breeding } \\
\text { lines }\end{array}$} & \\
\hline 5 & $\mathrm{G}_{5}=\mathrm{O}-0411-10-4$ & Stem \& leaf stipule red, ovate lanceolate leaf & & \\
\hline 6 & $\mathrm{G}_{6}=\mathrm{O}-043-7-9(2)$ & Stem \& leaf stipule red, narrow lanceolate leaf & & \\
\hline 7 & $\mathrm{G}_{7}=\mathrm{O}-049-1-3$ & Stem \& leaf stipule red, lanceolate leaf & & \\
\hline 8 & $\mathrm{G}_{8}=\mathrm{O}-0419-3-1$ & Stem, leaf stipule \& petiole red; ovate lanceolate leaf & & \\
\hline 9 & $\mathrm{G}_{9}=\operatorname{JRO}\left(\mathrm{S}_{1}\right)$ & Stem, leaf stipule \& petiole reddish; ovate lanceolate leaf & \multirow{4}{*}{$\begin{array}{l}\text { Controls (Pre- } \\
\text { released variety) } \\
\text { Exotic variety }\end{array}$} & \multirow{4}{*}{$\begin{array}{l}\text { Gene Bank, } \\
\text { BJRI }\end{array}$} \\
\hline 10 & $\mathrm{G}_{10}=$ BJRI Tossa pat $-5(\mathrm{O}-795)$ & Stem, leaf stipule \& petiole red; ovate leaf & & \\
\hline 11 & $\mathrm{G}_{11}=$ BJRI Tossa pat -8 (Robi- 1$)$ & Stem, leaf stipule \& petiole reddish, lanceolate leaf with glossy surface & & \\
\hline 12 & $\mathrm{G}_{12}=\mathrm{JRO}-524$ (Navin) & Full green plant, lanceolate leaf & & \\
\hline
\end{tabular}

\subsection{Plant Sampling and Preparation for Anatomy}

At 120days age, ten plants were selected randomly from the middle row of each genotype for anatomical and morphological studies. A rapid and nondestructive method was adopted for anatomical study, $3-4 \mathrm{~cm}$ long stem with fiber (phloem) and stick (xylem) from top, middle and basal parts of each selected genotype were excised out with sharp knife. The samples were labeled and preserved in formaldehyde acetic acid (FAA) solution [formalin: acetic acid: alcohol-5: 15: 80)] for further anatomical studies [20]. Transverse sections $(0.3-0.5 \mathrm{~mm}$ thin) were made using hand operated Microtome machine (WSL Lab Microtome-modified Reichert-type) [21] and the additional mucilage was removed by rinsing with clean water, and then stained with $1 \%$ safranin (aqueous) solution. Stained sections were mounted with a drop of glycerin-water on clear glass slide with a cover slip [22]. Transverse sections of jute stem were observed and anatomical data i.e. bark diameter, bark thickness, height of trapezoid, average width of trapezoid, area of trapezoid, average number of trapezoid, total fiber bundle area per section and number of bundle layer trapezoid ${ }^{-1}$ in jute plant were recorded carefully through microscopic study.

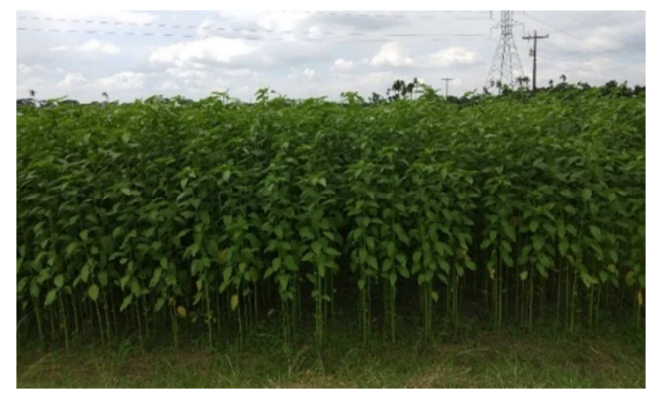

Figure 1. Growing of experimental tossa jute plants.

\subsection{Morphological Data Collection}

Jute plants were harvested at 120 days after sowing. Morphological data i.e. plant population in each plot, average plant height $(\mathrm{m})$, plant base diameter $(\mathrm{cm})$, green weight with leaves $\left(\mathrm{g}\right.$ plant $\left.{ }^{-1}\right)$, green weight without leaves $\left(\mathrm{g}\right.$ plant $\left.{ }^{-1}\right)$ were recorded from 40 plants selected randomly from each replicated plots of the treatments. Plants were tied into bundles with proper labeling (metallic label), and bundles of jute plants were aggregated and allowed to defoliate for 3-4 days. Then bundles were kept under water in 2-3 layers. In about 15-20 days, the retting was completed and then fibers were extracted manually, washed and air-sun dried by hanging from bamboo stick manually for data collection [11]. The minimum ratio of plant material to water in stagnant water was 1: 20 [23]. Then, data i.e. dry fiber yield (g plant $\left.{ }^{1}\right)$, dry stick yield $\left(\mathrm{g}\right.$ plant $\left.{ }^{-1}\right)$ were recorded from the same plants carefully. The fiber yield $\left(\mathrm{t} \mathrm{ha}^{-1}\right)$ was calculated based on the area and plant population of each plot.

\subsection{Analyses of Morphological and Anatomical Data}

All the data were compiled carefully using Microsoft Excel sheets. The analysis for variability and least significant differences (LSD) among the genotypes; significant association among all traits in morphological study and anatomical study were estimated followed by RCBD design using MS Excel program and statistical software statistix10 (Statistix10.0.0.9) [24]. Clustering and principal component analyses were done using statistical software XLSTAT (XLSTAT2020.1.3) [25].

\subsubsection{Statistical Parameters}

Mean, range, LSD, standard error (S. E.), standard deviation $(\sigma x)$ and coefficient of variation $(\mathrm{CV})$ for each character were estimated. The mean sum of square of genotype $\left(\mathrm{MS}_{\mathrm{G}}\right)$ and error $\left(\mathrm{MS}_{\mathrm{E}}\right)$ were estimated followed by Johnson et al. [26]. The $\mathrm{MS}_{\mathrm{E}}$ was considered as error variance $\left(\sigma_{\mathrm{E}}^{2}\right)$. LSD tests were checked from calculated and tabulated value of ' $F$ ' at both $\mathrm{P}>0.05$ and $\mathrm{P}>0.01$ level. Pearson correlation coefficient among all characters in all possible combinations were estimated using the formula given by Cohen [27].

\subsubsection{Variance \& Co-variance Matrices}

Genetic parameters like Genotypic and phenotypic variance of the trait (s) were calculated using the formulae (Eqn. $1 \& 2$ ); and the genotypic, phenotypic and environmental co-variance components between two traits were calculated using the formulae (Eqn. 3, 4, 5) suggested by Burton [28].

\subsubsection{Heritability}

The heritability in broad sense was estimated using the formula (Eqn. 6) suggested by Johnson et al. [26] and Burton and Devane [29].

\subsubsection{Genetic Advance}

The expected genetic advance for different characters 
under selection was estimated using the formula (Eqn. 7) suggested by Lush [30] and Johnson et al. [26]. Genetic advance in percentage of mean was calculated from the formula (Eqn. 8) given by Comstock and Robinson [31].

\subsubsection{Genotypic and Phenotypic Correlations}

The covariance components among the traits were computed using the formula (Eqn. 9). The genotypic and phenotypic correlations $\left(\mathrm{r}_{G_{X Y}}\right.$ and $\left.\mathrm{r}_{P_{X Y}}\right)$ for all possible combinations were estimated using these co-variance components and the formula (Eqn. 9-12) suggested by Karim et al., [32] and Johnson et al. [26].

These formulae along with parameters were stated in equations 1-14.

$$
\begin{aligned}
& \sigma_{\mathrm{G}}^{2}=\frac{\mathrm{MS}_{\mathrm{G}}-\mathrm{MS}_{\mathrm{E}}}{\mathrm{r}} \\
& \sigma_{\mathrm{P}}^{2}=\sigma_{\mathrm{G}}^{2}+\sigma_{\mathrm{E}}^{2} \\
& \operatorname{GCV}(\%)=\frac{\sqrt{\sigma_{G}^{2}}}{\bar{x}} \times 100 \\
& \operatorname{PCV}(\%)=\frac{\sqrt{\sigma_{\mathrm{P}}^{2}}}{\overline{\mathrm{x}}} \times 100 \\
& \operatorname{ECV}(\%)=\frac{\sqrt{\sigma_{\mathrm{E}}^{2}}}{\overline{\mathrm{x}}} \times 100 \\
& \mathrm{~h}_{\mathrm{bs}}^{2}(\%)=\frac{\sqrt{\sigma_{\mathrm{G}}^{2}}}{\sqrt{\sigma_{\mathrm{P}}^{2}}} \times 100 \\
& \mathrm{GA}=\frac{\sqrt{\sigma_{\mathrm{G}}^{2}}}{\sqrt{\sigma_{\mathrm{P}}^{2}}} \times K \times \sigma_{P} \\
& \operatorname{GAM}(\%)=\frac{\mathrm{GA}}{\bar{X}} \times 100 \\
& \left.\operatorname{Cov}_{X Y}=\sum_{i=1,2, \ldots n}^{N}\left[\left(X_{i}-\bar{X}\right) \cdot\left(Y_{i}-\bar{Y}\right)\right] / N-1\right) \\
& r_{X Y}=\frac{\operatorname{Cov}_{X Y}}{\sqrt{\sigma^{2} X \times \sigma^{2} Y}} \\
& \mathrm{r}_{G_{X Y}}=\frac{\operatorname{Cov}_{\mathrm{G}} \mathrm{XY}}{\sqrt{\sigma_{\mathrm{G}}^{2} \mathrm{X} \times \sigma_{\mathrm{G}}^{2} \mathrm{Y}}} \\
& r_{P_{X Y}}=\frac{\operatorname{Cov}_{P} X Y}{\sqrt{\sigma_{P}^{2} X \times \sigma_{P}^{2} Y}}
\end{aligned}
$$

\subsubsection{Genotype by Environment Model Formulation $\mathrm{G} \times$ E Model}

$$
y i j=\mu+g i+e i+(g e) i j+\text { error }
$$

Where $y i j$ is the observed trait, $\mu$ is the grand mean, $g i$ is the genotypic effect, $e i$ is the environmental effect which is the two evaluation cycles, and $(g e) i j$ is the $\mathrm{G} \times \mathrm{E}$ interaction effect as proposed by DeLacy et al. [33].

$\mathrm{G} \times$ E Phenotypic Variance Component Model

$$
\sigma_{\mathrm{P}}^{2}=\sigma_{\mathrm{G}}^{2}+\frac{\sigma^{2} \mathrm{GE}}{\mathrm{ne}}+\frac{\sigma_{\mathrm{e}}^{2}}{\mathrm{ne}, \mathrm{nr}}
$$

Where, $\frac{\sigma^{2} \mathrm{GE}}{\mathrm{ne}}$ is $\mathrm{G} \times \mathrm{E}$ variance component, and $\frac{\sigma_{\mathrm{e}}^{2}}{\mathrm{ne}, \mathrm{nr}}$ is the error variance component. The subscripts $n e$ and $n r$ imply number of environments and number of replications, respectively, as proposed by Tiwari et al. [34].

Here,

$\mathrm{MS}_{\mathrm{G}}=$ Genotypic mean square value

$\mathrm{MS}_{\mathrm{E}}=$ Error mean square value

$\mathrm{r}=$ Number of replication

$\sigma_{\mathrm{G}}^{2}=$ Genotypic variance $(\mathrm{GV})$

$\sigma_{\mathrm{P}}^{2}=$ Phenotypic variance $(\mathrm{PV})$

$\sigma_{\mathrm{E}}^{2}=$ Error variance $=\frac{\mathrm{MS}_{\mathrm{E}}}{\mathrm{r}}$

$\mathrm{GCV}=$ Genotypic coefficient of variation (\%)

$\mathrm{PCV}=$ Phenotypic coefficient of variation (\%)

$\mathrm{ECV}=$ Environmental coefficient of variation (\%)

$\overline{\mathrm{X}}$ or $\overline{\mathrm{Y}}=$ Mean value of the variable $\mathrm{X}$ or $\mathrm{Y}$ being evaluated

$\mathrm{h}_{\mathrm{b}}^{2}=$ Heritability in broad sense $(\%)$

$\mathrm{K}=2.06$ (Standardized selection intensity at 0.05 level)

$\sigma_{\mathrm{P}}=$ Phenotypic standard deviation

$\mathrm{GA}=$ Genetic advance is taken as percent of the mean assuming selection of the superior $5 \%$ of the breeding lines GAM $(\%)=$ Genetic advance in percentage of mean

$\operatorname{Cov}_{\mathrm{XY}}=$ Covariance between character $\mathrm{X}$ and $\mathrm{Y}$ $\mathrm{N}=$ Number of observation in the variable $\mathrm{X}$ or $\mathrm{Y}$

\begin{tabular}{|c|c|c|c|c|c|c|c|c|}
\hline SV & d. f. & $\begin{array}{l}\text { Plant height } \\
\text { (m) }\end{array}$ & $\begin{array}{l}\text { Plant base } \\
\text { diameter }(\mathrm{mm})\end{array}$ & $\begin{array}{l}\text { Green weight } \\
\text { with leaves }\end{array}$ & $\begin{array}{l}\text { Green weight } \\
\text { without leaves }\end{array}$ & $\begin{array}{l}\text { Fiber } \\
\text { yield }\end{array}$ & $\begin{array}{l}\text { Jute Fiber yield } \\
\left(\mathrm{t} \mathrm{ha}^{-1}\right)\end{array}$ & $\begin{array}{l}\text { Jute stick yield } \\
\left.\text { (kg plant }^{-1}\right)\end{array}$ \\
\hline Genotype & 11 & $0.07 * *$ & $4.95 * *$ & $2495.58 * *$ & $2304.84 * *$ & $15.74 * *$ & $0.74 * *$ & $201.55 * *$ \\
\hline Replication & 2 & 0.01 & 1.29 & 153.88 & 27.22 & 3.32 & 0.12 & 27.3 \\
\hline Error & 22 & 0.002 & 0.47 & 6.05 & 23.57 & 0.44 & 0.02 & 4.03 \\
\hline Total & 35 & --- & --- & --- & --- & --- & --- & --- \\
\hline CV $(\%)$ & & 1.47 & 4.43 & 1.09 & 2.29 & 5.50 & 5.02 & 5.25 \\
\hline
\end{tabular}
$\sigma^{2} \mathrm{X}$ or $\sigma^{2} \mathrm{Y}=$ Variance of variable $\mathrm{X}$ or $\mathrm{Y}$ $\sigma_{\mathrm{G}}^{2} \mathrm{X}$ or $\sigma_{\mathrm{G}}^{2} \mathrm{Y}=$ Genotypic variance of variable $\mathrm{X}$ or $\mathrm{Y}$ $\mathrm{r}_{\mathrm{XY}}=$ Correlation between variable $\mathrm{X}$ and $\mathrm{Y}$

$\mathrm{r}_{\mathrm{G}_{\mathrm{XY}}}=$ Genotypic correlation between variable $\mathrm{X}$ and $\mathrm{Y}$

$\mathrm{r}_{\mathrm{P}_{\mathrm{XY}}}=$ Phenotypic correlation between variable $\mathrm{X}$ and $\mathrm{Y}$

\section{Results and Discussion}

\subsection{Morphological Study}

The analyses results revealed that, genotype mean squares for all traits studied were highly significant (Table 2) reflecting the existing of large variability among tested genotypes and this variability can be further utilized for tossa jute improvement program.

Table 2. Analysis of variance (ANOVA) for different morphological characters of selected 12 genotypes.

Note: SV-Source variation, df-Degree of freedom (probability of random selection from the total population), **> significant at 0.01 probability level, respectively, $C V$-Coefficient of variation 


\subsubsection{Plant Height}

Among all genotypes, the genotype Acc.1306 showed the highest plant height (3.22m), and O-049-1-3, Acc.1306, O0512-6-2, BJRI Tossa pat-5 showed almost similar results for plant height (Table 3). The genotypes with higher plant height compared to controls would be used as breeding materials to develop new variety which was also corroborated by Zhang et al. [35].

\subsubsection{Base Diameter}

The plant with higher base diameter is important for fiber crops. The fiber is mainly produced from basal and middle portion of the plant. In this investigation, Acc. 1318 gave maximum base diameter $(16.63 \mathrm{~mm})$ with higher fiber content followed by O-049-1-3, O-0512-6-2, JRO-524, O-0411-10-4, O-0419-3-1 compared to controls BJRI Tossa pat-5 \& BJRI Tossa pat- 8 (Table 2). The highest diameter with more fiber (phloem) content at base of the tossa jute plant contribute to fiber yield content and could be used for varietal development, it was agreed with Zhang et al. [35].

\subsubsection{Plant Weight}

The fiber yield is related with green weight of jute plant. Green weight of jute plant means the fresh weight of the plant with leaves. Green weight without leaves is also important to fiber yield of jute plant [35]. In this experiment, the Acc.1318 and Acc.1306 showed maximum weight with and without leaves of the jute plant compared to other plant materials (Table 2).

\subsubsection{Yield Performances}

Higher fiber yield is the main objective of jute plant. The genotype Acc. 1318) gave higher fiber yield (3.55 $\left.\mathrm{t} \mathrm{ha}^{-1}\right)$ followed by Acc.1306, O-0512-6-2, JRO-524, BJRI tossa pat-5, JRO $\left(\mathrm{S}_{1}\right)$, O-0411-10-4. For fiber content, Acc.1318, Acc.1306, O-0512-6-2 performed well than the controls (Table 3). These genotypes would be further cultivated for the next generation to develop high yielding new varieties. The jute breeding materials as well as the hybridized offspring(s) providing higher fiber content are generally considered for developing high yielding varieties of jute crop $[36,37]$. Jute sticks are useful materials which are now using in various aspects to produce charcoal, desk board of valuable cars, ink [38]. From this study, the genotypes (Acc. 1318, Acc. 1306, O-0512-6-2, O-0411-10-4, O-049-1-3) giving higher stem height, base diameter, fiber content showed higher stick yield per plant compared to controls (Table 3 ).

\subsubsection{Genotypic and Phenotypic Correlation Coefficient}

The estimated correlations using formulae (Eqn. 9-12) among the studied characters would be useful to breeders for parental selection [39]. The positive significant correlations were observed for all the characters considering all genotypes at both genotypic and phenotypic level (Table 4). The values of genotypic correlations were higher than phenotypic correlation for all traits. Plant height showed highly significant association** with plant base diameter $\left(\mathrm{r}_{\mathrm{g}}=0.723\right.$, $\left.r_{p}=0.640\right)$, green weight leaves $\left(r_{g}=0.674, r_{p}=0.654\right)$, green weight without leaves $\left(\mathrm{r}_{\mathrm{g}}=0.583, \mathrm{r}_{\mathrm{p}}=0.561\right)$, jute fiber yield $\left(r_{\mathrm{g}}=0.632, r_{\mathrm{p}}=0.598\right)$, and significant relation* with jute stick yield $\left(r_{\mathrm{g}}=0.457, \mathrm{r}_{\mathrm{p}}=0.436\right)$ of the plants depicting the possibility of phenotypic selection for jute crop improvement based on these traits (Table 4).

Table 3. Performance mean of selected 12 genotypes for yield and yield related morphological traits.

\begin{tabular}{|c|c|c|c|c|c|c|c|}
\hline Variety/Lines & $\begin{array}{l}\text { Plant height } \\
\text { (m) }\end{array}$ & $\begin{array}{l}\text { Base diameter } \\
(\mathrm{mm})\end{array}$ & $\begin{array}{l}\text { Green weight } \\
\text { with leaves } \\
\left(\text { g plant }^{-1}\right) \\
\end{array}$ & $\begin{array}{l}\text { Green weight } \\
\text { without leaves } \\
\left(\text { g plant }^{-1}\right)\end{array}$ & $\begin{array}{l}\text { Dry fiber } \\
\text { yield (g } \\
\left.\text { plant }^{-1}\right) \\
\end{array}$ & $\begin{array}{l}\text { Dry fiber } \\
\text { yield }\left(\mathrm{t} \mathrm{ha} \mathbf{~}^{-1}\right)\end{array}$ & $\begin{array}{l}\text { Jute Stick yield } \\
\left(\text { g plant }^{-1}\right)\end{array}$ \\
\hline Acc. 1306 & $3.15 \mathrm{abc}$ & $15.40 \mathrm{~b}$ & $260.27 \mathrm{a}$ & $246.13 a$ & $13.83 b$ & $3.45 b$ & $51.40 \mathrm{a}$ \\
\hline Acc. 1318 & $3.22 \mathrm{a}$ & $16.63 \mathrm{a}$ & $261.93 a$ & $247.67 \mathrm{a}$ & $16.93 a$ & $3.55 \mathrm{a}$ & $52.70 \mathrm{a}$ \\
\hline O-0512-6-2 & $3.15 b c$ & $16.22 \mathrm{ab}$ & $260.17 \mathrm{a}$ & $245.27 \mathrm{a}$ & $13.50 \mathrm{~b}$ & $3.38 \mathrm{~b}$ & $40.40 \mathrm{~b}$ \\
\hline O-0412-9-4 & $2.73 \mathrm{~h}$ & $14.00 \mathrm{c}$ & $208.87 f$ & $206.80 b c$ & $9.20 \mathrm{f}$ & $2.27 \mathrm{~g}$ & $35.00 \mathrm{c}$ \\
\hline O-043-7-9 & $2.88 \mathrm{fg}$ & $15.60 \mathrm{ab}$ & $214.80 \mathrm{de}$ & $199.00 \mathrm{~cd}$ & $10.13 \mathrm{ef}$ & $2.50 \mathrm{fg}$ & $34.80 \mathrm{c}$ \\
\hline O-049-1-3 & $3.18 \mathrm{ab}$ & $16.23 \mathrm{ab}$ & $213.80 \mathrm{de}$ & $195.87 d$ & $11.07 \mathrm{de}$ & $2.92 \mathrm{de}$ & $39.40 \mathrm{~b}$ \\
\hline O-0419-3-1 & $3.10 \mathrm{cde}$ & $16.07 \mathrm{ab}$ & $227.87 \mathrm{c}$ & $211.47 b$ & $9.63 \mathrm{f}$ & $2.71 \mathrm{ef}$ & $37.00 \mathrm{bc}$ \\
\hline $\mathrm{JRO}\left(\mathrm{S}_{1}\right)$ & $3.04 \mathrm{e}$ & $15.40 \mathrm{~b}$ & $224.07 \mathrm{c}$ & $213.07 \mathrm{~b}$ & $12.23 c$ & $3.05 \mathrm{~cd}$ & $38.20 \mathrm{bc}$ \\
\hline BJRI Tossa pat-5 & $3.13 \mathrm{bcd}$ & $15.13 b c$ & $212.20 \mathrm{ef}$ & $198.80 \mathrm{~cd}$ & $13.20 \mathrm{bc}$ & $3.30 \mathrm{bc}$ & $22.80 \mathrm{e}$ \\
\hline BJRI Tossa pat- 8 & $2.84 \mathrm{~g}$ & $12.00 \mathrm{~d}$ & $161.33 \mathrm{~g}$ & $146.67 \mathrm{e}$ & $11.50 \mathrm{de}$ & $2.80 \mathrm{ef}$ & $29.00 \mathrm{~d}$ \\
\hline Maximum & 3.22 & 16.63 & 261.93 & 247.67 & 16.93 & 3.55 & 52.70 \\
\hline Mean & 3.04 & 15.42 & 225.93 & 211.58 & 12.06 & 3.02 & 38.24 \\
\hline $\operatorname{LSD}_{(0.05)}$ & $0.07 * *$ & $1.16^{* *}$ & $4.16^{* *}$ & $8.22 * *$ & $1.12 * *$ & $0.26^{* *}$ & $3.40 * *$ \\
\hline CV (\%) & 1.47 & 4.43 & 1.09 & 2.29 & 5.50 & 5.02 & 5.25 \\
\hline $\bar{x} \pm \mathrm{SE}$ & $3.04 \pm 0.025$ & $15.42 \pm 0.39$ & $225.93 \pm 1.42$ & $211.58 \pm 2.80$ & $12.06 \pm 0.38$ & $3.02 \pm 0.09$ & $38.24 \pm 1.16$ \\
\hline
\end{tabular}

Note: $C V$ (Coefficient of variation) $=(\sqrt{ }$ EMS/Mean) $\times 100$, LSD (0.05)-Least significant difference at 5\% probability level, values with same letters are statistically insignificant for the same variable. 
Table 4. Partitioning of genotypic and phenotypic correlation coefficients among morphological traits.

\begin{tabular}{|c|c|c|c|c|c|c|}
\hline Characters & Correlations & $\begin{array}{l}\text { Stem base } \\
\text { diameter }\end{array}$ & $\begin{array}{l}\text { Green weight } \\
\text { with leaves }\end{array}$ & $\begin{array}{l}\text { Green weight } \\
\text { without leaves }\end{array}$ & $\begin{array}{l}\text { Dry fiber yield } \\
\left(\text { g plant }^{-1}\right)\end{array}$ & $\begin{array}{l}\text { Dry stick yield } \\
\left.\text { (g plant }^{-1}\right)\end{array}$ \\
\hline \multirow{2}{*}{ Plant height (m) } & $r_{g}$ & $0.723 * *$ & $0.674 * *$ & $0.583^{* *}$ & $0.632 * *$ & $0.457 *$ \\
\hline & $\mathrm{r}_{\mathrm{p}}$ & $0.640 * *$ & $0.654 * *$ & $0.561 * *$ & $0.598 * *$ & $0.436^{*}$ \\
\hline \multirow{2}{*}{ Plant base diameter (mm) } & $\mathrm{r}_{\mathrm{g}}$ & & $0.827 * *$ & $0.785 * *$ & $0.363 *$ & $0.554 * *$ \\
\hline & $r_{p}$ & & $0.751 * *$ & $0.707 * *$ & $0.321^{*}$ & $0.500 * *$ \\
\hline \multirow{2}{*}{ Green weight with leaves (g plant ${ }^{-1}$ ) } & $\mathrm{r}_{\mathrm{g}}$ & & & $0.968 * *$ & $0.578 * *$ & $0.745 * *$ \\
\hline & $r_{p}$ & & & $0.956 * *$ & $0.561 * *$ & $0.729 * *$ \\
\hline \multirow{2}{*}{$\begin{array}{l}\text { Green weight without leaves ( } \mathrm{g} \\
\text { plant }^{-1} \text { ) }\end{array}$} & $r_{g}$ & & & & $0.533 * *$ & $0.768 * *$ \\
\hline & $r_{p}$ & & & & $0.513 * *$ & $0.745^{* *}$ \\
\hline \multirow{2}{*}{ Dry fiber yield $\left(\mathrm{g} \mathrm{plant}^{-1}\right)$} & $r_{g}$ & & & & & $0.507 * *$ \\
\hline & $r_{p}$ & & & & & $0.483 *$ \\
\hline
\end{tabular}

Note: $r_{g}=$ Genotypic correlation and $r_{p}=$ Phenotypic correlation; The Values between 0.5 to 1.0 or -1.0 to -0.5 denote strong correlation**, and values between -0.5 to -0.3 or 0.3 to 0.5 denote moderate correlation*; and others values denote weak or very weak/non-significant correlation (Riduan, 2008); * and ** denote significant at 0.05 and 0.01 level of probability

Plant height and stem base diameter have direct effects on green weight followed by dry fiber and stick yield of jute plants. The plant base diameter showed highly significant correlation** with green weight with leaves $\left(\mathrm{r}_{\mathrm{g}}=0.827\right.$, $\left.\mathrm{r}_{\mathrm{p}}=0.751\right)$, without leaves $\left(\mathrm{r}_{\mathrm{g}}=0.785, \mathrm{r}_{\mathrm{p}}=0.707\right)$; dry stick yield $\left(\mathrm{r}_{\mathrm{g}}=0.554, \mathrm{r}_{\mathrm{p}}=0.500\right)$; and significant relation* with dry fiber yield $\left(\mathrm{r}_{\mathrm{g}}=0.363, \mathrm{r}_{\mathrm{p}}=0.321\right)$ of jute plants at genotypic and phenotypic levels (Table 4). The results revealed that, only the base diameter can strongly push to enhance the green weight and dry stick yield of jute plants; and but with plant height, it can increase the dry fiber yield of jute plants very strongly. Ghosh et al. [40] observed that, plant height and plant base diameter are highly associated with green weight, dry fiber and dry stick yield in jute plants.

\subsubsection{Genetic Components for Morphological Characters}

Correlation coefficient determines the simple relations among the traits. Estimation of genetic parameters, heritability and genetic advance using the formulae (Eqn. 18) for the characters as to correlation coefficient gives more detailed information on the characters contributing to yield, so it is commonly used by plant breeders to determine yield and yield contributing characters [41]. The genetic parameters i.e. genotypic, phenotypic variance $\left(\sigma_{G}^{2}, \sigma_{P}^{2}\right.$; genotypic, phenotypic and environmental coefficients of Variation (GCV, PCV, ECV\%), heritability in broad sense $\left(\mathrm{h}^{2}{ }_{\mathrm{bs}} \%\right)$, genetic advance (GA) and genetic advance in percent of mean (GAM\%) were estimated for six characters (Table 5). The highest values for $\sigma_{G}^{2}(829.843), \sigma_{P}^{2}$ (831.860), $\mathrm{h}_{\text {bs }}^{2}(99.76 \%)$ and GA (59.27) were recorded in green weight with leaves per plant, and the highest GCV (21.22\%), PCV (21.65\%), ECV (5.25\%) and GAM (43.28\%) were found in dry stick yield of jute plants (Table 5). Plant height showed the lowest $\sigma_{\mathrm{G}}^{2}(0.023), \sigma_{\mathrm{P}}^{2}(0.024), \mathrm{GCV}$ (5.03\%), PCV (5.17\%), GA (0.31) and GAM (10.11\%), and plant base diameter showed the lowest broad sense heritability (90.98) and green weight with leaves gave the lowest ECV (1.09). Generally, quantitative characters are highly influenced by the environment. According to Deshmukh et al. [42], PCV and GCV values greater than $20 \%$ are regarded as high, whereas values less than $10 \%$ are considered to be low and values between 10 and $20 \%$ to be medium. Dry jute stick yield recorded higher values, plant height and base diameter showed lower values, and green weight and dry fiber yield of jute plants showed medium values for PCV, GCV. Due to lower environmental effects, all traits gave lower ECV values. All traits recorded greater values for PCV than GCV indicating high contribution of genotypic effects for phenotypic expression of such characters. High and moderate values of PCV and GCV indicated the existence of substantial variability for such characters and selection may be effective based on these characters. Similar finding was reported earlier for plant height, stem base diameter, dry fiber yield per plant, dry fiber yield per hectare of land, dry stick yield per plant, for green weight per plant [43].

Estimates of $\mathrm{h}^{2}$ bs ranged from $90.569 \%$ for base diameter to $99.758 \%$ for green weight with leaves per jute plant. The heritability values categorized as high $(>80 \%)$, moderate high $(60-79 \%)$, medium (40-59\%) and low $(<40 \%)$ [38]. Accordingly, the estimate of heritability of all characters studied were very high, and it was agreed with the findings of Sreelathakumary and Rajamory [44]. The characters with high heritability indicated the small effects of the environment factors to the phenotype, and selection for such characters is fairly easy due to high additive effect [45]. The characters with high GCV, PCV coupled with high $\mathrm{h}^{2}$ bs would give the best picture of the amount of advance to be expected from selection [46].

Knowledge on heritability coupled with GA is more useful for genetic improvement through selection [26] and to predict the expected genetic gain from one selection cycle [47]. Estimates of GA for dry fiber yield per plant was $4.31 \mathrm{~g}$, indicating that, whenever we select the best, 5\% high yielding genotypes as parents, mean dry fiber yield plant ${ }^{-1}$ of the offspring could be improved a large of 4.31 g, i.e., mean genotypic value of the new population for dry fiber yield per plant will be improved from $12.06 \mathrm{~g}$ to $16.37 \mathrm{~g}$. In the same way, plant height will be improved from $3.04 \mathrm{~m}$ to $3.35 \mathrm{~m}$; $15.42 \mathrm{~mm}$ to $17.83 \mathrm{~mm}$ for stem base diameter; $3.02 \mathrm{t} \mathrm{ha}^{-1}$ to $3.82 \mathrm{t} \mathrm{ha}^{-1}$ for fiber yield and $38.24 \mathrm{~g}$ plant ${ }^{-1}$ to $54.79 \mathrm{~g}$ plant ${ }^{-1}$ for dry stick yield. 
Table 5. Variance, covariance, heritability, genetic advances of morphological traits studied.

\begin{tabular}{lllllllll}
\hline Characters & $\mathbf{G V}\left(\boldsymbol{\sigma}_{\mathbf{G}}^{\mathbf{2}}\right)$ & $\mathbf{P V}\left(\boldsymbol{\sigma}_{\mathbf{P}}^{\mathbf{2}}\right)$ & $\mathbf{G C V}(\mathbf{\%})$ & $\mathbf{P C V}(\mathbf{\%})$ & $\mathbf{E C V}(\mathbf{\%})$ & $\mathbf{h}_{\text {bs }}^{\mathbf{2}}(\mathbf{\%})$ & $\mathbf{G A}$ & $\mathbf{G A M}(\mathbf{\%})$ \\
\hline Plant height $(\mathrm{m})$ & 0.02 & 0.02 & 5.03 & 5.17 & 1.47 & 97.26 & 0.31 & 10.11 \\
Base diameter $(\mathrm{mm})$ & 1.49 & 1.80 & 7.93 & 8.71 & 4.43 & 90.98 & 2.41 & 15.60 \\
Green weight with leaves $\left(\mathrm{g} \mathrm{plant}{ }^{-1}\right)$ & 829.84 & 833.88 & 12.75 & 12.78 & 1.09 & 99.76 & 59.27 & 26.23 \\
Green weight without leaves $\left(\mathrm{g} \mathrm{plant}^{-1}\right)$ & 760.42 & 776.14 & 13.03 & 13.17 & 2.29 & 98.98 & 56.52 & 26.71 \\
Jute fiber yield $\left(\mathrm{g} \mathrm{plant}^{-1}\right)$ & 5.10 & 5.39 & 18.46 & 18.99 & 5.42 & 97.24 & 4.31 & 35.23 \\
Jute fiber yield $\left(\mathrm{t} \mathrm{ha}^{-1}\right)$ & 0.24 & 0.25 & 16.12 & 16.64 & 5.02 & 96.92 & 0.80 & 26.50 \\
Jute Stick yield $\left(\mathrm{g} \mathrm{plant}^{-1}\right)$ & 65.84 & 68.53 & 21.22 & 21.65 & 5.25 & 98.02 & 16.55 & 43.28 \\
\hline
\end{tabular}

Note: $\bar{x}=$ Mean vale, SE-Standard error, $G V\left(\sigma_{P}^{2}\right)$-Genotypic variation, $P V\left(\sigma_{P}^{2}\right)$-Phenotypic variation, GCV-Genotypic coefficient of variation, $P C V$ Phenotypic coefficient of variation, $h_{b s}^{2}$-Heritability in broad sense, GA-Genetic advance, GAM (\%)-Genetic advance as percentage of the mean

The GAM ranged from $10.216 \%$ to $43.272 \%$ for plant height and dry stick yield per plant, respectively. According to Jonhson et al. [26] the value of GAM is categorized as low $(<10 \%)$, moderate $(10-20 \%)$ and high (> 20\%). The GAM of plant height and stem base diameter were classified as moderate, whereas other characters were high. High $\mathrm{h}^{2}$ bs along with the GAM is usually more helpful in predicting gain under selection than heritability alone. In the present study, high heritability with moderate GAM are exhibited by plant height and stem base diameter while the other characters were exhibited high heritability with high GAM reflecting the presence of additive gene action for the expression of these traits which is fixable for next generations, and selection in the next population based on this character. Similar results were also reported by Sreelathakumary and Rajamory [44] in local chili pepper.

\subsection{Anatomy of Tossa Jute Plant}

Maiti [48] opined that, jute fibers obtained from the stem (commercially known as bast fibers) lie embedded in the softer tissue of the bark. This type of bast fiber known as phloem fiber which is derived from cambial meristematic activity which cuts of fiber initials that grow longitudinally along the axis within the bark. Each of these cells, pointed at both ends and with a lumen at the center, is called an ultimate fiber cell (Figures 2,3).

\subsubsection{ANOVA for Anatomical Study}

The analyses of variance (Table 6) revealed significant differences for anatomical characters indicating the presence of variability among all jute genotypes. The mean values of different anatomical characters were estimated (Table 7) and the pattern of fiber development in 12 tossa jute genotypes were studied [Figure 4 (i-xii)]. Maity et al. [8] was firstly proposed the possibility of prediction of fiber quality and yield capacity from anatomy of jute plant.

Table 6. Analysis of variance components (mean square values) for anatomical characters.

\begin{tabular}{|c|c|c|c|c|c|c|c|c|c|}
\hline Traits & Plant stem & $\begin{array}{l}\text { Genotype } \\
\text { (d.f.=11) }\end{array}$ & $\begin{array}{l}\text { Replication } \\
\text { (d.f.=2) }\end{array}$ & $\begin{array}{l}\begin{array}{l}\text { Error } \\
\text { (d.f. }=22)\end{array} \\
\end{array}$ & Traits & $\begin{array}{l}\text { Plant } \\
\text { stem }\end{array}$ & $\begin{array}{l}\text { Genotype } \\
\text { (d.f.=11) }\end{array}$ & $\begin{array}{l}\text { Replication } \\
\text { (d.f.=2) }\end{array}$ & $\begin{array}{l}\begin{array}{l}\text { Error } \\
(d . f .=22)\end{array} \\
\end{array}$ \\
\hline \multirow{4}{*}{$\begin{array}{l}\text { Bark } \\
\text { diameter } \\
(\mathrm{mm})\end{array}$} & Base & $10.702 * *$ & 0.701 & 0.991 & \multirow{4}{*}{$\begin{array}{l}\text { Number of } \\
\text { trapezoid } \\
\text { section }^{-1}\end{array}$} & Base & $135.846^{* *}$ & 67.861 & 27.922 \\
\hline & Middle & $6.031 * *$ & 1.021 & 0.351 & & Middle & $61.838^{* *}$ & 18.111 & 17.414 \\
\hline & Top & $1.797 * *$ & 0.098 & 0.183 & & Top & $509.867^{* *}$ & 11.111 & 14.505 \\
\hline & Overall & $3.803 * *$ & 0.092 & 0.021 & & Overall & $62.343^{* *}$ & 6.303 & 3.581 \\
\hline \multirow{4}{*}{$\begin{array}{l}\text { Bark } \\
\text { thickness } \\
(\mathrm{mm})\end{array}$} & Base & $0.566 * *$ & 0.115 & 0.047 & \multirow{4}{*}{$\begin{array}{l}\text { Total bundle } \\
\text { area (sqmm) } \\
\text { section }^{-1}\end{array}$} & Base & $161.952 *$ & 94.442 & 51.571 \\
\hline & Middle & $0.490 * *$ & 0.010 & 0.024 & & Middle & $97.497 * *$ & 9.194 & 15.854 \\
\hline & Top & $0.186^{* *}$ & 0.002 & 0.013 & & Top & $14.395^{* *}$ & 2.384 & 1.998 \\
\hline & Overall & $0.194 * *$ & 0.009 & 0.010 & & Overall & $46.604 * *$ & 6.487 & 5.242 \\
\hline \multirow{4}{*}{$\begin{array}{l}\text { Area of a } \\
\text { trapezoid } \\
(\mathrm{sqmm})\end{array}$} & Base & $0.025^{*}$ & 0.011 & 0.008 & \multirow{4}{*}{$\begin{array}{l}\text { Bundle layer } \\
\text { trapezoid }^{-1}\end{array}$} & Base & $4.222 * *$ & 0.886 & 0.235 \\
\hline & Middle & $0.021 * *$ & 0.001 & 0.004 & & Middle & $1.952 * *$ & 0.063 & 0.168 \\
\hline & Top & $0.0055^{* *}$ & 0.0039 & 0.0009 & & Top & $1.058 * *$ & 0.307 & 0.063 \\
\hline & Overall & $0.0093 * *$ & 0.0011 & 0.0013 & & Overall & $0.971 * *$ & 0.272 & 0.051 \\
\hline
\end{tabular}

\subsubsection{Bark Diameter}

In the anatomy of jute plants (Figure 4: i-xii), the highest bark diameters were recorded in Acc. 1318 at the plant base, middle and overall plant $(7.56,14.78,13.35 \mathrm{~mm}$, rep.), and $7.89 \mathrm{~mm}$ at middle of plant stem in O-043-7-9. Considering full plant, the good results for bark diameter were found in
Acc. $1318(13.35 \mathrm{~mm})$, JRO $\left(\mathrm{S}_{1}\right)(11.59 \mathrm{~mm})$ and Acc. 1306 (11.30) compared to control varieties (Table 7). These materials would be used as parent material in hybridization program. Jute genotypes with higher bark diameter contribute to fiber (phloem) and stick (xylem) yield [49]. 

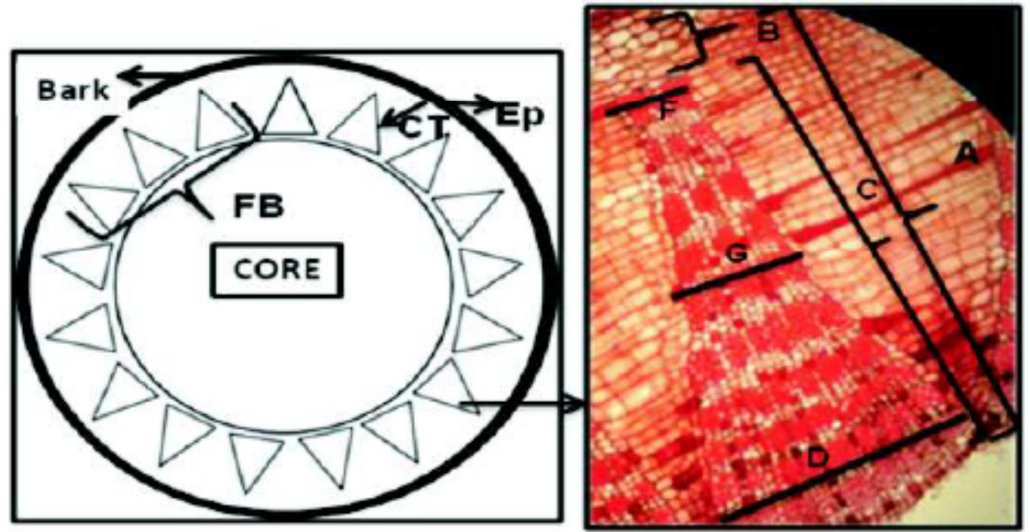

Figure 2. Pattern of distribution of fiber cells in cross section of jute plant [14]. Note: FB-Fiber bundle, Ep-Epidermis, CT-Cortex, A-Total bark diameter, BDifference between fiber wedge tip, C-Average length of fiber bundle, D-Average width of fiber bundle at base, F-Average width of fiber bundle at top, $G$ Average width of fiber bundle at middle.

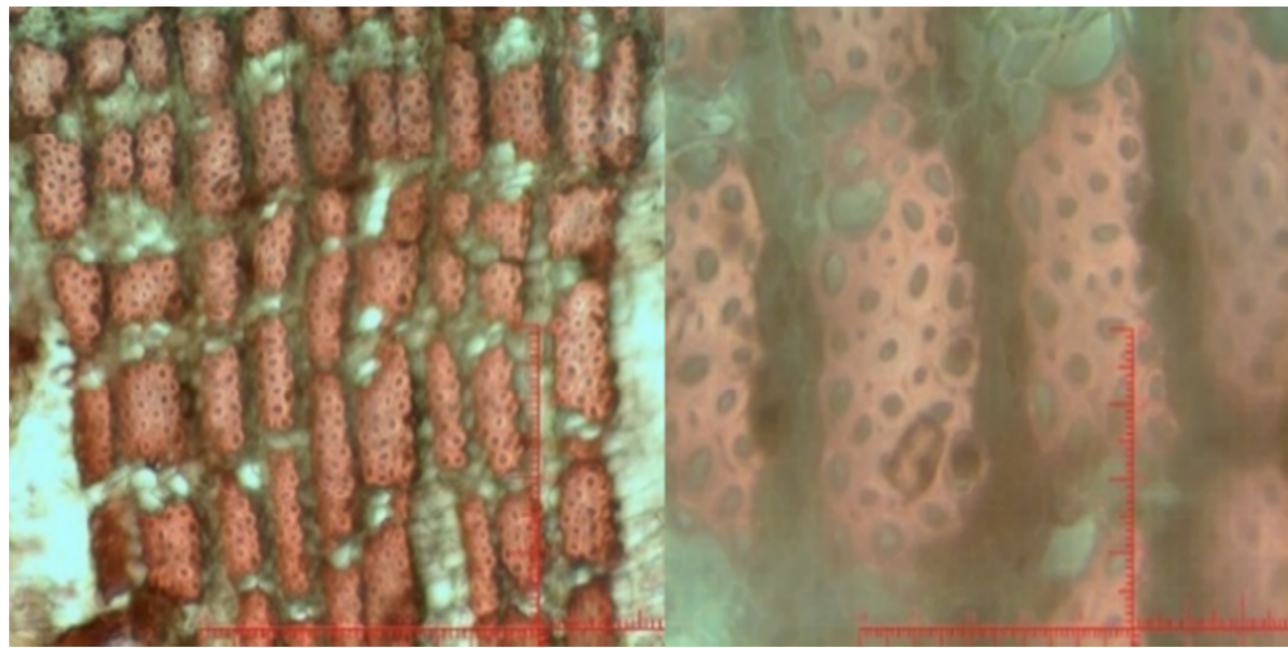

Figure 3. Zoomed in view of schlerenchymatous fiber cells (phloem fiber) of tossa jute plant.

\subsubsection{Bark Thickness}

The space between the upper surface of cambium cell to the epidermis of phloem tissue is known as the bark thickness of jute plant [49]. Phloem fibers or bast fiber are made up of sclerenchymatous cells (Figure 3 ) which are generally absent in primary phloem but are found in the secondary phloem [50] The highest bark thickness at base, middle and top of the plants were found in JRO $\left(\mathrm{S}_{1}\right)(4.55 \mathrm{~mm})$, Acc. 1318 $(3.91 \mathrm{~mm})$ and O-043-7-9 (2.37), resp. In the full plant, the highest bark thickness was recorded in Acc. 1318 (3.42mm) followed by JRO $\left(\mathrm{S}_{1}\right)$ (3.24mm), Acc. 1306 (3.17mm) compared to controls (Table 7). Bark thickness is an important criterion for phenotypic selection of breeding materials in Jute plant breeding approaches [49].

\subsubsection{Area of a Trapezoid}

The highest area of a trapezoid was found in Acc. 1318 at base $(0.53 \mathrm{sqmm})$, top $(0.51 \mathrm{sqmm})$, middle $(0.27 \mathrm{sqmm})$ and overall full plant $(0.43 \mathrm{sqmm})$ followed by Acc. 1306 (0.41sqmm) than the control varieties (Table 7$)$. The jute genotypes with maximum area of a trapezoid contribute to higher fiber yield and these genotypes would be used as parent (s) for hybridization purposes [51].

\subsubsection{Average Number of Trapezoid}

The average number of trapezoid was found higher in the transverse section of BJRI Tossa pat-5 at base (78.33); in Acc. 1318 at middle (66.67), full plant (60.56); in top of O049-1-3 (51.67). Considering the full plant, the Acc. 1318, O049-1-3, O-0512-6-2 gave the good results for trapezoid number $(60.56,59.33,57.56$, resp.) in the transverse section of jute plant (Table 7). Jute genotype (s) with higher plant height and base diameter gave maximum number of trapezoid per transverse section. The maximum number of trapezoid give more area of fiber bundle. These results were corroborated by Sengupta and Palit [49].So, the Acc. 1318 will be considered as a good genotype in respect of trapezoid number as well as fiber bundle area. 


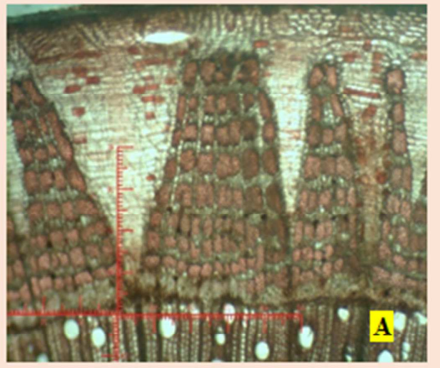

$\mathrm{G}_{1}=$ Acc. 1306

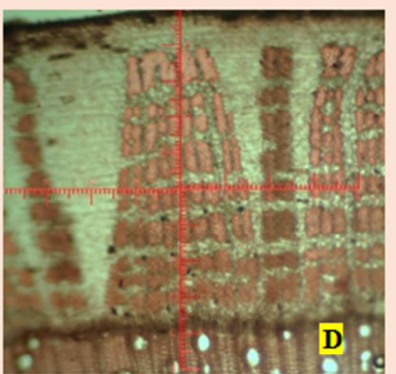

$\mathrm{G}_{4}=0-0412-9-4$

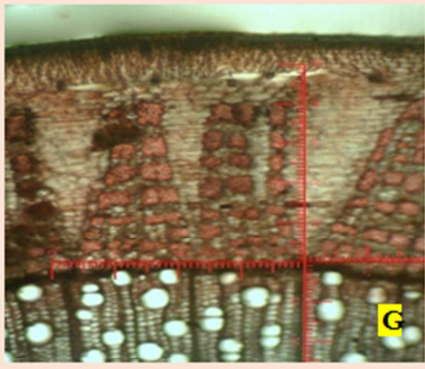

$\mathrm{G}_{7}=\mathrm{O}-049-1-3$

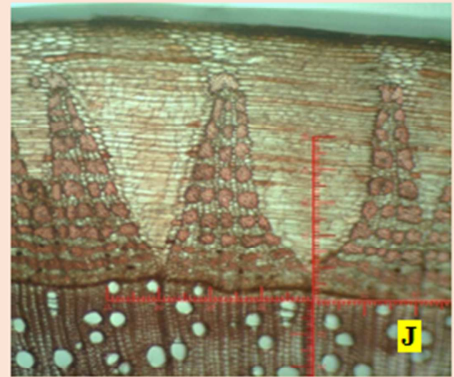

$\mathrm{G}_{10}=\mathrm{BJRI}$ Tossa pat-5 (O-795)

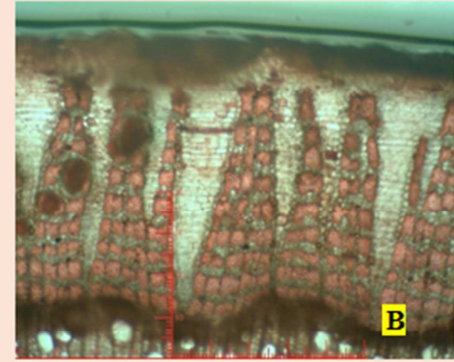

$\mathrm{G}_{2}=$ Acc. 1318

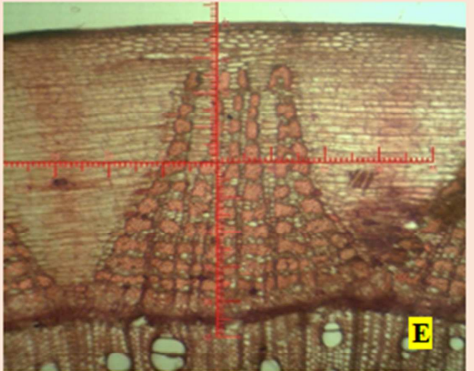

$\mathrm{G}_{5}=\mathrm{O}-0411-10-4$

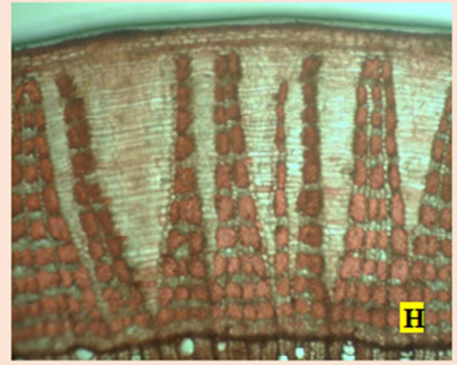

$\mathrm{G}_{8}=\mathrm{O}-0419-3-1$

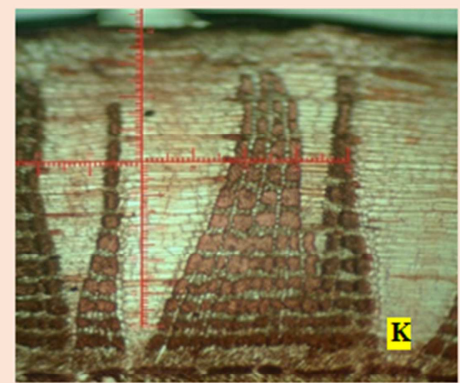

$\mathrm{G}_{11}=$ BJRI Tossa pat-8 (Robi-1)

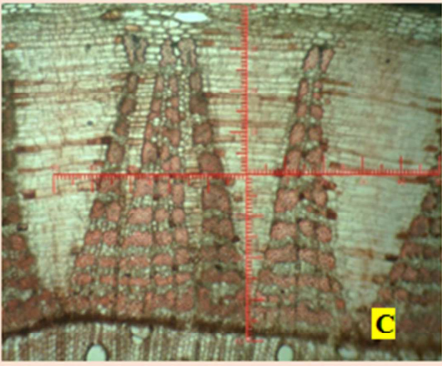

$\mathrm{G}_{3}=\mathrm{O}-0512-6-2$

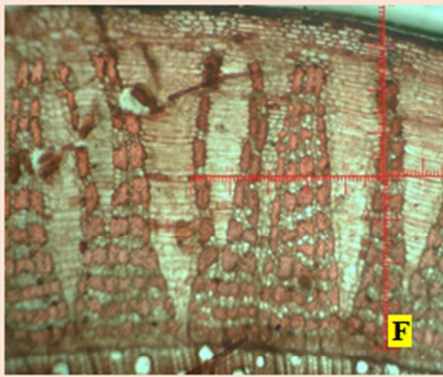

$\mathrm{G}_{6}=\mathrm{O}-043-7-9$

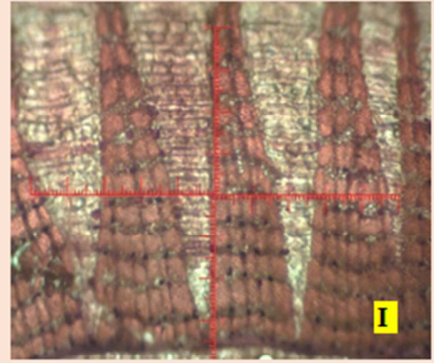

$\mathrm{G}_{9}=\operatorname{JRO}\left(\mathrm{S}_{1}\right)$

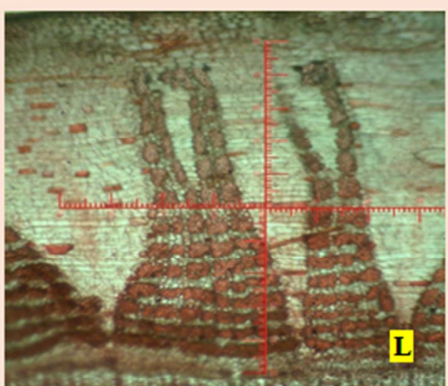

$\mathrm{G}_{12}=\mathrm{JRO}-524$ (Navin)

Figure 4. (i-xii) Distribution of fiber cells in cross section of different 12 tossa jute genotypes.

\subsubsection{Fiber Bundle Area}

It was found that, Acc. 1318 gave higher fiber bundle area in transverse section at middle $(33.98 \mathrm{~mm})$ and top $(11.33 \mathrm{~mm})$ of jute stem, and also considering the full plant (27.88mm). BJRI Tossa pat-5 showed the highest fiber bundle area $(39.16 \mathrm{~mm})$ at base of the stem. In respect of full plant, the fiber bundle area recorded in Acc. 1318 (27.88mm) and Acc. 1306 (22.95mm) which were higher than all controls (Table 7). The bark diameter, bark thickness, number of trapezoid and area of trapezoid contributing to total fiber bundle area in jute plant would be the criteria for phenotypic selection for fiber yield [52].

\subsubsection{Fiber Bundle Area}

It was found that, Acc. 1318 gave higher fiber bundle area in transverse section at middle $(33.98 \mathrm{~mm})$ and top $(11.33 \mathrm{~mm})$ of jute stem, and also considering the full plant 
(27.88mm). BJRI Tossa pat-5 showed the highest fiber bundle area $(39.16 \mathrm{~mm})$ at base of the stem. In respect of full plant, the fiber bundle area recorded in Acc. 1318 (27.88mm) and Acc. 1306 (22.95mm) which were higher than all controls (Table 7). The bark diameter, bark thickness, number of trapezoid and area of trapezoid contributing to total fiber bundle area in jute plant would be the criteria for phenotypic selection for fiber yield [52].

Table 7. Mean performance of 12 tossa jute genotypes for anatomical characters.

\begin{tabular}{|c|c|c|c|c|c|c|c|c|c|c|c|c|}
\hline \multirow[t]{2}{*}{ Lines/ Variety } & \multicolumn{4}{|c|}{ Bark diameter $(\mathrm{mm})$ of jute stem at } & \multicolumn{4}{|c|}{ Bark thickness (mm) of jute plant at } & \multicolumn{4}{|c|}{$\begin{array}{l}\text { Area of a trapezoid (sqmm) in trans. } \\
\text { section at }\end{array}$} \\
\hline & Base & Middle & Top & Overall & Base & Middle & Top & Overall & Base & Middle & Top & Overall \\
\hline Acc. 1306 & 14.33 & 12.06 & 7.50 & 11.30 & 4.21 & 3.17 & 2.12 & 3.17 & 0.51 & 0.45 & 0.26 & 0.41 \\
\hline Acc. 1318 & 17.56 & 14.78 & 7.72 & 13.35 & 4.00 & 3.91 & 2.34 & 3.42 & 0.53 & 0.51 & 0.27 & 0.43 \\
\hline O-0512-6-2 & 14.00 & 10.44 & 7.44 & 10.63 & 3.61 & 2.84 & 2.17 & 2.87 & 0.30 & 0.28 & 0.20 & 0.26 \\
\hline O-0412-9-4 & 14.07 & 10.47 & 7.52 & 10.69 & 3.64 & 2.85 & 2.19 & 2.89 & 0.31 & 0.31 & 0.21 & 0.28 \\
\hline O-043-7-9 green & 12.22 & 10.39 & 7.89 & 10.17 & 3.27 & 2.74 & 2.37 & 2.79 & 0.39 & 0.31 & 0.24 & 0.31 \\
\hline O-049-1-3 & 13.39 & 10.17 & 7.22 & 10.26 & 3.56 & 2.83 & 2.11 & 2.83 & 0.42 & 0.22 & 0.22 & 0.29 \\
\hline O-0419-3-1 & 11.39 & 9.22 & 6.83 & 9.15 & 3.37 & 2.42 & 2.13 & 2.64 & 0.33 & 0.28 & 0.27 & 0.29 \\
\hline $\operatorname{JRO}\left(\mathrm{S}_{1}\right)$ & 15.44 & 11.56 & 7.78 & 11.59 & 4.55 & 2.95 & 2.22 & 3.24 & 0.53 & 0.31 & 0.22 & 0.35 \\
\hline BJRI Tossa pat-5 & 15.44 & 11.56 & 5.83 & 10.94 & 4.31 & 3.01 & 1.65 & 2.99 & 0.50 & 0.36 & 0.16 & 0.34 \\
\hline BJRI Tossa pat- 8 & 10.61 & 10.22 & 7.56 & 9.46 & 4.22 & 2.32 & 2.07 & 2.87 & 0.47 & 0.23 & 0.22 & 0.31 \\
\hline Maximum & 17.56 & 14.78 & 7.89 & 13.35 & 4.55 & 3.91 & 2.37 & 3.42 & 0.53 & 0.51 & 0.27 & 0.43 \\
\hline Minimum & 10.61 & 9.22 & 5.44 & 9.15 & 3.27 & 2.32 & 1.64 & 2.60 & 0.30 & 0.22 & 0.14 & 0.26 \\
\hline Mean & 13.74 & 10.98 & 7.14 & 10.62 & 3.80 & 2.87 & 2.06 & 2.91 & 0.43 & 0.32 & 0.21 & 0.32 \\
\hline S.E. & 0.81 & 0.48 & 0.35 & 0.117 & 0.18 & 0.13 & 0.09 & 0.084 & 0.07 & 0.05 & 0.02 & 0.030 \\
\hline CV (\%) & 7.25 & 5.40 & 5.99 & 1.35 & 5.71 & 5.36 & 5.44 & 3.52 & 21.15 & 19.71 & 13.97 & 11.26 \\
\hline $\operatorname{LSD}_{(0.05)}$ & $1.67 * *$ & $1.00 * *$ & $0.72 * *$ & $0.243 * *$ & $0.37 * *$ & $0.26^{* *}$ & $0.19^{* *}$ & $0.17 * *$ & $0.15^{*}$ & $0.11 * *$ & $0.05 * *$ & $0.06^{* *}$ \\
\hline
\end{tabular}

Table 7. Continued.

\begin{tabular}{|c|c|c|c|c|c|c|c|c|c|c|c|c|}
\hline \multirow[t]{2}{*}{ Lines/Variety } & \multicolumn{4}{|c|}{$\begin{array}{l}\text { Average no. of trapezoid per trans. section } \\
\text { of stem at }\end{array}$} & \multicolumn{4}{|c|}{$\begin{array}{l}\text { Total fiber bundle area (sqmm) in trans. } \\
\text { section of stem at }\end{array}$} & \multicolumn{4}{|c|}{ Fiber bundle layer in trapezoid at } \\
\hline & Base & Middle & Top & Overall & Base & Middle & Top & Overall & Base & Middle & Top & Overall \\
\hline Acc. 1306 & 70.67 & 50.67 & 37.33 & 52.89 & 36.19 & 22.91 & 9.76 & 22.95 & 11.11 & 8.67 & 4.00 & 7.93 \\
\hline Acc. 1318 & 72.33 & 66.67 & 42.67 & 60.56 & 38.33 & 33.98 & 11.33 & 27.88 & 11.67 & 9.44 & 4.56 & 8.56 \\
\hline O-0512-6-2 & 71.00 & 59.67 & 42.00 & 57.56 & 21.35 & 16.63 & 8.22 & 15.40 & 9.56 & 7.11 & 4.22 & 6.96 \\
\hline O-0412-9-4 & 69.33 & 59.67 & 0.42 & 43.14 & 21.67 & 16.93 & 7.66 & 15.42 & 9.73 & 7.29 & 4.27 & 7.10 \\
\hline O-043-7-9 green & 60.67 & 56.67 & 43.67 & 53.67 & 23.67 & 17.32 & 10.79 & 17.26 & 10.11 & 7.44 & 5.22 & 7.59 \\
\hline O-049-1-3 & 67.33 & 59.00 & 51.67 & 59.33 & 28.50 & 12.98 & 11.13 & 17.54 & 11.89 & 7.67 & 5.00 & 8.19 \\
\hline O-0419-3-1 & 60.67 & 59.67 & 43.33 & 54.56 & 20.06 & 16.70 & 11.32 & 16.03 & 10.22 & 7.11 & 4.67 & 7.33 \\
\hline $\mathrm{JRO}\left(\mathrm{S}_{1}\right)$ & 64.00 & 49.67 & 45.00 & 52.89 & 34.16 & 15.25 & 9.81 & 19.74 & 12.67 & 8.56 & 4.89 & 8.70 \\
\hline BJRI Tossa pat-5 & 78.33 & 57.33 & 36.33 & 57.33 & 39.16 & 20.53 & 5.68 & 21.79 & 13.22 & 8.11 & 3.89 & 8.41 \\
\hline BJRI Tossa pat- 8 & 54.67 & 53.33 & 47.33 & 51.78 & 25.78 & 12.13 & 10.37 & 16.09 & 12.44 & 6.56 & 4.56 & 7.85 \\
\hline Maximum & 78.33 & 66.67 & 51.67 & 60.56 & 39.16 & 33.98 & 11.33 & 27.88 & 13.22 & 9.44 & 5.22 & 8.70 \\
\hline Minimum & 54.67 & 49.67 & 0.42 & 43.14 & 19.51 & 12.13 & 5.68 & 14.34 & 9.56 & 6.56 & 3.11 & 6.96 \\
\hline Mean & 65.86 & 57.11 & 39.26 & 54.08 & 28.36 & 18.35 & 9.01 & 18.58 & 11.28 & 7.77 & 4.35 & 7.80 \\
\hline S.E. & 4.31 & 3.41 & 3.11 & 1.545 & 5.86 & 3.25 & 1.15 & 1.870 & 0.40 & 0.33 & 0.20 & 0.19 \\
\hline CV (\%) & 8.02 & 7.31 & 9.70 & 3.50 & 25.32 & 21.69 & 15.69 & 12.33 & 4.29 & 5.27 & 5.76 & 2.91 \\
\hline $\operatorname{LSD}_{(0.05)}$ & $8.95 * *$ & $7.07 * *$ & $6.45^{* *}$ & $3.20 * *$ & $12.16^{*}$ & $6.74 * *$ & $2.39 * *$ & $3.88 * *$ & $0.82 * *$ & $0.69 * *$ & $0.42^{* *}$ & $0.38 * *$ \\
\hline
\end{tabular}

\subsubsection{Fiber Bundle Layer in Trapezoid}

Maximum fiber bundle layer trapezoid ${ }^{-1}$ was found in transverse section at base of BJRI Tossa pat-5 (13.22); at middle of Acc. 1318 (9.44); at top of O-043-7-9 (5.22). In the full plant, the highest fiber bundle layer trapezoid ${ }^{-1}$ was found in JRO $\left(\mathrm{S}_{1}\right)$ followed by Acc. 1318 (8.56), O-049-1-3
(8.19) (Table 7). The number of fiber bundle layer in trapezoid contributes to fiber bundle area as well as fiber yield in jute plant [53].

\subsubsection{Associations for Anatomical Characters}

The genotypic and phenotypic association among the anatomical characters were estimated using the formulae 
(Eqn. 9-12). The anatomical characters of 12 jute plants showed highly significant and positive correlations with one another; where, average number of trapezoid per transverse section showed significant relation with other characters at both genotypic and phenotypic levels, and non-significantly associated with area of trapezoid at phenotypic level (Table 8). The bark thickness, area of a trapezoid, number of trapezoid and number of fiber bundle layer in trapezoid contribute to total fiber bundle area in jute stem as well as fiber and stick yield in jute plants. These anatomical features would be the selection criteria to the jute breeders for jute crop improvement in Bangladesh [54].

Table 8. Partitioning of genotypic and phenotypic correlation coefficients among anatomical traits.

\begin{tabular}{|c|c|c|c|c|c|c|}
\hline Characters & Corr. & BT & AT & AnTS $^{-1}$ & TBAS $^{-1}$ & BLT $^{-1}$ \\
\hline \multirow{2}{*}{ BDM } & $r_{g}$ & $0.926 * *$ & $0.768^{* *}$ & $0.352 *$ & $0.864 * *$ & 0.610 ** \\
\hline & $r_{p}$ & $0.874 * *$ & $0.664 * *$ & $0.330^{*}$ & $0.767 * *$ & $0.576^{* *}$ \\
\hline \multirow{2}{*}{ BT } & $r_{g}$ & & $0.876^{* *}$ & $0.279 *$ & $0.893 * *$ & $0.730 * *$ \\
\hline & $\mathrm{r}_{\mathrm{p}}$ & & $0.723^{* *}$ & $0.250^{*}$ & $0.758 * *$ & $0.658^{* *}$ \\
\hline \multirow{2}{*}{ AT } & $r_{g}$ & & & $0.292 *$ & $0.916^{* *}$ & $0.738 * *$ \\
\hline & $r_{p}$ & & & 0.240 & $0.841 * *$ & $0.608 * *$ \\
\hline \multirow{2}{*}{$\operatorname{AnTS}^{-1}$} & $r_{g}$ & & & & $0.486^{* *}$ & $0.487 * *$ \\
\hline & $r_{p}$ & & & & $0.410^{*}$ & $0.436^{*}$ \\
\hline \multirow{2}{*}{ TBAS $^{-1}$} & $r_{g}$ & & & & & $0.779 * *$ \\
\hline & $r_{p}$ & & & & & 0.660 ** \\
\hline
\end{tabular}

Note: BDM-Bark diameter (mm), BT-Bark thickness (mm), AT-Area of a trapezoid (sqmm), AnTS ${ }^{-1}$-Average no. of trapezoid per T.section, TBAS ${ }^{-1}$-Total bundle area per T.section (sqmm), BLT-No. of bundle layer trapezoid ${ }^{-1}$ * and ** denote significant at 0.05 and 0.01 probability level

\subsubsection{Genetic Components for Anatomical Characters}

The analyses for six anatomical data of jute plant (Table 9) revealed that, the genotypic and phenotypic variances $\left(\sigma_{\mathrm{g}}^{2}, \sigma_{\mathrm{P}}^{2}\right)$ were ranged from 0.003 to 19.587 and 0.004 to 21.975 for area of a trapezoid and average number of trapezoid T. section ${ }^{-1}$. The genotypic, phenotypic and environmental co-variances were ranged from 2.332 to $19.985 \% ; 2.455$ to $22.374 \%$; 0.942 to $12.323 \%$ for bark thickness and total fiber bundle in the jute plants. The GCV values were higher than PCV values for all anatomical characters. The ECV values were found very lowest for all characters indicating the lower effects of environmental factors on jute plant growth. All the traits showed high heritability $(>80 \%)$ where the highest value (99.449) was recorded in bark diameter and lowest (86.874) in area of a trapezoid. The higher genetic advance was found in average number of trapezoid per T. section (8.866) followed by total fiber bundle area per $T$. section (7.252) indicating the possibility of increasing these traits from 18.58 to 25.832 sqmm total fiber bundle area; from 54.08 to 62.946 number of trapezoid section ${ }^{-1}$ contributing to fiber yield improvement in jute plants.

Table 9. Variance, covariance, heritability, genetic advances of anatomical traits studied.

\begin{tabular}{|c|c|c|c|c|c|c|c|c|}
\hline Characters & $\mathbf{G V}\left(\sigma_{\mathrm{g}}^{\mathbf{2}}\right)$ & $\operatorname{PV}\left(\sigma_{p}^{2}\right)$ & GCV (\%) & PCV (\%) & $\operatorname{ECV}(\%)$ & $\mathbf{h}_{\mathrm{bs}}^{2}$ & GA & GAM (\%) \\
\hline BDM & 1.261 & 1.275 & 10.572 & 10.631 & 1.365 & 99.449 & 2.306 & 21.717 \\
\hline BT & 0.061 & 0.068 & 2.332 & 2.455 & 0.942 & 94.972 & 0.497 & 4.684 \\
\hline AT & 0.003 & 0.004 & 16.137 & 18.576 & 11.267 & 86.874 & 0.099 & 31.092 \\
\hline $\operatorname{AnTS}^{-1}$ & 19.587 & 21.975 & 8.184 & 8.668 & 3.499 & 94.412 & 8.866 & 16.394 \\
\hline $\mathrm{TBAS}^{-1}$ & 13.787 & 17.282 & 19.985 & 22.374 & 12.323 & 89.319 & 7.252 & 39.032 \\
\hline BLT & 0.307 & 0.341 & 7.100 & 7.483 & 2.895 & 94.879 & 1.112 & 14.255 \\
\hline
\end{tabular}

The genetic advance in percent of mean ranged from $4.684 \%$ to $39.032 \%$ for bark diameter and total fiber bundle area section 1 . Johnson et al. [26] categorized the value of GAM as low $(<10 \%)$, moderate $(10-20 \%)$ and high $(>20 \%)$. Accordingly, the GAM values for the total fiber bundle area section ${ }^{-1}$, area of a trapezoid and bark diameter were categorized as high; for the average number of trapezoid section ${ }^{-1}$ and bundle layer trapezoid $^{-1}$ were categorized as medium and for the bark thickness was low. The characters having high to medium GAM values indicate the greater possibility of improvement for these characters as well as fiber yield of the jute plants. High $h_{b s}^{2}$ along with the GAM is usually more helpful in predicting gain under selection than heritability alone. The total fiber bundle area in transverse section coupled with higher GV, PV, GCV,
PCV, $\mathrm{h}_{\mathrm{bs}}^{2}$, GA and GAM would be the principal selection criteria for improving fiber yield in jute plants which was agreed with the findings of Islam et al. [55].

\section{Conclusion}

The variabilities existing among the tested genotypes for the studied morphological and anatomical traits indicate the high potentials for jute crop improvement through breeding techniques. The jute genotypes i.e. Acc. 1318, Acc. 1306, O0512-6-2 providing good results for plant height, base diameter and dry fiber yield in morphological study, and total trapezoidal area in $T$. section, average number of trapezoid in $\mathrm{T}$. section, bark diameter, bark thickness in anatomical study 
depicting the variability as well as possibility of tossa jute improvement. In separate analyses, the fiber yield and yield related studied morphological traits (plant height, base diameter, green weight with and without leaves of plant and dry fiber yield of jute plants) and anatomical characters (total trapezoidal area in $\mathrm{T}$. section, average number of trapezoid in T. section, bark diameter, area of a trapezoid, bark thickness, fiber bundle layer trapezoid ${ }^{-1}$ ) showing significant association with one another, and coupled with high genetic and phenotypic variance-covariance components; high heritability; high \& moderate genetic advance and genetic advance in percent of mean would be used for selection of jute genotypes as well as jute crop improvement for fiber yield. The anatomical characters may be considered as an easy and effective method for screening genotypes within a short time. In general, the study revealed that direct selection scheme would be more promising and encouraging than indirect selection for improving yield. This could be the nature of wild accessions or advanced breeding lines because of their better adaptive traits to variable environmental conditions which have important implications for sustainable jute cultivation.

\section{Conflict of Interests}

All the authors have no conflict of interest to declare.

\section{Funding Information}

There was no funding source for this work from outside; completely supported from the revenue budget of Bangladesh Jute Research Institute.

\section{Author's Contribution}

All the authors jointly conceptualized the experimental strategy, financial supports. They supported in field data collection, laboratory works and helped in data compilation, analyses and manuscript writing, submission, correction etc.

\section{Data Availability}

The data information will be available on urgent request of the authorized person only.

\section{Abbreviations}

BJRI-Bangladesh Jute Research Institute; JAES-Jute Agricultural Experiment Station;

BCSIR-Bangladesh Council of Scientific and Industrial Research;

\section{Acknowledgements}

The authors acknowledge Bangladesh Jute Research Institute, Manik Mia Avenue, Dhaka-1207, Bangladesh for providing the seed materials, laboratory \& field facilities to carry out this research work successfully.

\section{References}

[1] Islam MM, MS Ali (2017). Agronomic Research Advances in Jute Crops of Bangladesh. AASCIT Journal of Biology. Vol. 3, No. 6, pp. 34-46. http://www.aascit.org/journal/archive?journalId=980\&issueId $=9800306$

[2] Kar CS, A Kundu, D Sarkar, MK Sinha and BS Mahapatra (2009). Genetic diversity in jute (Corchorus spp) and its utilization: a review. Indian Journal of Agricultural Sciences, $\begin{array}{lllll}\text { August } & 2009, & 79 & \text { (8): }\end{array}$ https://www.researchgate.net/publication/235666679

[3] Kundu, A, N Topdar, D Sarkar et al. (2013). Origins of white (Corchorus capsularis L.) and dark (C. olitorius L.) jute: a reevaluation based on nuclear and chloroplast microsatellites. J. Plant Biochem. Biotechnol. 22, 372-381. DOI: https://doi.org/10.1007/s13562-012-0165-7

[4] Kundu BC (1951). "Origin of jute," Indian Journal of Plant Breeding, vol. 11, pp. 95-99. https://www.indianjournals.com/Mobile/SearchResult.aspx?qu ery $=3$

[5] Palve SM and MK Sinha (2005). "Genetic variation and interrelationships among fiber yield attributes in secondary gene pool of Corchorus spp. SABRAO Journal of Breeding and $\quad$ Genetics. $\quad 37 \quad$ (1): 55-64. https://www.cabdirect.org/cabdirect/FullTextPDF/2005/20053 136195. pdf

[6] Samira R, Moosa MM, Alam MM, Keka SI, Khan H (2010). In silico analysis of jute SSR library and experimental verification of assembly. Plant Omics Journal, 2010, 3: 5765. https://www.pomics.com/khan_3_2_2010_57_65.pdf

[7] Satya P, AK Mahapatra and RK Maiti (2011). Fiber anatomy structure: a good predictor for fiber yield and fiber quality in Corchorus capsularis L. Int. J. Bios. Stress Mangt., 2 (3): 26367. http://connection. ebscohost.com/c/articles/66463960/

[8] Maity S, S Chowdhury, AK Datta (2012). Jute Biology, Diversity, Cultivation, Pest Control, Fiber Production and Genetics. In: Lichtfouse E. (eds) Organic Fertilisation, Soil Quality and Human Health. Sustainable Agriculture Reviews, vol 9. Springer, Dordrecht. DOI: https://doi.org/10.1007/97894-007-4113-3 9

[9] Roy A, A Bandyopadhyay, AK Mahapatra, SK Ghosh, NK Singh, KC Bansal, KR Koundal and T Mohapatra (2006). Evaluation of genetic diversity in jute (Corchorus species) using STMS, ISSR and RAPD markers. Plant Breeding Journal, V-125, Issue-3, P: 292-297. DOI: https://doi.org/10.1111/j.1439-0523.2006.01208.x

[10] Basu A, Ghosh M, Meyer R, Powell W, Basak SL, Sen SK (2004). Analysis of genetic diversity in cultivated jute determined by means of SSR markers and AFLP profiling. Crop Sci., 44: 678-685. DOI: https://doi.org/10.2135/cropsci2004.6780

[11] Islam MM and MM Rahman (2013). Advances in jute and allied fibers post-harvest processing technologies in Bangladesh: Adoption constraints, prospect and future thrust. $\begin{array}{llll}\text { Research Web } \quad P u b, & \text { (2): } & \text { 20-30. }\end{array}$ https://www.academia.edu/7905084/ 
[12] Nwangburuka C and OA Denton (2012). Heritability, Character Association and Genetic Advance in Six Agronomic and Yield Related Characters in Leaf Corchorus olitorius L. International Journal of Agricultural Research, 7 (7): 367-375. DOI: 10.3923/ijar.2012.367.375

[13] Ngomuo M, T Stoilova, T Feyissa and PA Ndakidemi (2017). Characterization of Morphological Diversity of Jute Mallow (Corchorus spp.). Hindawi: International Journal of Agronomy, Volume 2017, Article ID 6460498, 12 pages. DOI: https://doi.org/10.1155/2017/6460498

[14] Kumar V, PK Singh, AS Dudhane, DK De and P Satya (2014). Anatomical and morphological characteristics of nine jute genotypes. Journal of Crop and Weed, 10 (2): 334-339. http://www.cropandweed.com/vol10issue2/ pdf2005/54.pdf

[15] Karmkar KS, C Bhattacharya and A Bakshi (2007). A comparative study on simple correlation coefficient value in capsularis Jute at different population level. J. Crop Weed, 3: 30-32. DOI: http://www.cropandweed.com/archives/2007/vol3issue2/7.pdf

[16] Maiti RK and P Satya (2009). Fiber bundle anatomy determines the yield potentials, and fiber quality of bast fiber (Long Fiber): A hypothesis. Int. J. Agril. Env. Biotech. 2 (4): 41-46. https://www.cabdirect.org/cabdirect/FullTextPDF/2010/201030 17083.pdf

[17] https://www.google.com.bd/maps/For geographical location of the experimental regions.

[18] Mukul MM, S Rahman, MM Islam, SN Begum \& L Hassan (2015). Molecular characterization of rice genotypes for Zinc biosynthetic gene (s) using microsatellite simple sequence repeat (SSR) markers. Asian Journal of Medical and Biological Research, 1 (2), 187-197. DOI: https://doi.org/10.3329/ajmbr.v1i2.25611

[19] Gomez AK and AA Gomez (1983). Statistical Procedures for Agricultural Research. Book: International Rice Research Institute, Los Banos, Laguna, Philippines. $2^{\text {nd }}$ Edition. https://www.academia.edu/2456341/statistical_Procedures_for _Agricultural_Research?auto=download

[20] Verma PK (2008). Preservation of botanical specimens retaining the natural colour pigments. J. Histotechnol; 30; $173-190$. https://shodhganga.inflibnet.ac.in/bitstream/10603/53605/1/01_titl e.pdf

[21] Gärtner H and FH Schweingruber (2013). Microscopic Preparation Techniques for Plant Stem Analysis. Swiss Federal Research Institute WSL, 8903 Birmensdorf, Switzerland. https://www.dora.lib4ri.ch/wsl/islandora/object/wsl: 9994

[22] Tolivia D and J Tolivia (1987). Fasga: A new polychromatic method for simultaneous and differential staining of plant tissues. Journal of Microscopy, Volume148, Issue1, October 1987, Pages 113-117. https://doi.org/10.1111/j.1365-2818.1987.tb02859.x

[23] JSG-International Jute Study Group (2009). Low cost retting of jute/kenaf/mesta for quality up-gradation, JCI and BJRI, Dhaka, Bangladesh. https://nanopdf.com/ download/low-costretting-of-jute-kenaf-mesta-for-quality-up_pdf

[24] https://statistix.informer.com/10.0/. Statistix 10- Analytical software (2020). (Statistix 10.0.0.9),

[25] Addinsoft (2020). XLSTAT statistical and data analysis solution. New York, USA. https://www.xlstat.com.

[26] Johnson HW, HF Robinson and RW Comstock (1955).
Estimates of genetic and environment variability in Soybean. Agronomy Journal, 47: 314-318. DOI: https://doi.org/10.2134/agronj1955.00021962004700070009x

[27] Cohen J (1988). Statistical Power Analysis for the Behavioral Sciences, 2nd ed. Hillsdale, NJ: Erlbaum. http://www.utstat.toronto.edu/ brunner/oldclass/378f16/readin gs/Cohen Power.pdf

[28] Burton GW (1952). Quantitative inheritance in grasses. 6th Intl. Grassland Cong. Proc. 1: 227-238. https://www.semanticscholar.org/paper/

[29] Burton, G. W. and Devane, E. H. (1953). Estimating heritability in tall fesscusce from replicated clone natural materials. Journal of Agronomy, 45: 171-181. DOI: https://doi.org/10.2134/agronj1953.00021962004500100005x

[30] Lush JL (1949). Heritability of quantitative characters in farm animals. Proc. Of Intercropping. Cong. Genetica Heridita (Suppl.): 1949; 356-357. DOI: https://doi.org/10.1111/j.16015223.1949.tb03347.x

[31] Comstock RE and HF Robinson (1952). Genetic parameters, their estimation and significance. Proc. 6th Intercropping. Grassland Cong. 1: 284-291.

[32] Karim D, Siddique MNA, Sarkar U, Hasnat MZ \& Sultana J (2014). Phenotypic and genotypic correlation co-efficient of quantitative characters and character association of aromatic rice. Journal of Bioscience and Agriculture Research, 01 (01), 36-48. DOI: https://doi.org/10.18801/ jbar.010114.05

[33] DeLacy IH, KE Basford, M Cooper, JK Buil and CG McLaren (1996). "Analysis of multi-environment trials - An historical perspective," in Plant Adaptation and Crop Improvement, M. Cooper and G. L. Hammer, Eds., pp. 39-124, CAB International, Wallingford, England. https://espace.library.uq.edu.au/view/UQ:fa3288d

[34] Tiwari DN, SR Tripathi, MP Tripathi, N Khatri and BR Bastola (2019). Genetic Variability and Correlation Coefficients of Major Traits in Early Maturing Rice under Rainfed Lowland Environments of Nepal. Hindawi: Advances in Agriculture, Volume 2019, Article ID 5975901, 9 pages. https://doi.org/10.1155/2019/5975901

[35] Zhang L, Ibrahim AK, Niyitanga S, Zhang L, Qi J (2019). Jute (Corchorus spp.) Breeding. In: Al-Khayri J., Jain S., Johnson D. (eds) Advances in Plant Breeding Strategies: Industrial and Food Crops. Springer, Cham. DOI: https://doi.org/10.1007/978-3-030-23265-8_4

[36] Khatun R, MM Islam, M Al Hussain, N Parvin and K Sultana (2009). Performance study of newly developed jute variety BJRI Deshi-7 (BJC-2142). Int. J. Sustain. Agril. Tech., 5 (4): 12-18. https://www.researchgate.net/publication/ 313314160

[37] Singh BD (2001). Plant Breeding: Principles and Methods, 6th ed., Kalyani Publishers, New Delhi, India. http://14.139.206.50:8000/cgi-bin/koha/opacdetail.pl?biblionumber $=171744$

[38] BCSIR- Bangladesh Scientific and Industrial Research Council (2018). Central Report. http://bcsir.portal.gov.bd/

[39] Aditya JP, P Bhartiya, A Bhartiya (2011). Genetic variability, heritability and character association for yield and component characters in soybean (G. $\max$ (L.) Merrill). Journal of Central European Agriculture, 12 (1), p: 27-34. DOI: /10.5513/JCEA01/12.1.877 
[40] Ghosh RK, Sreewongchail T, Nakasathien1 S and Phumichai1 C (2013). Phenotypic variation and the relationships among jute (Corchorus species) genotypes using morpho-agronomic traits and multivariate analysis. Australian J. Crop Sci., 7: 830-42. http://www.cropj.com/phumichai_7 6_2013_830_842.pdf

[41] Mukul MM, SN Begum, MM Islam, MSR Khanom, MK Saha, S Ar-Raffi and L Hassan (2014). Phenotypic diversity analysis of iron rich rice landraces. Asian Australas. J. Biosci. Biotechnol. 2016, 1 (1), 15-22. https://www.ebupress.com/journal/ aajbb/2016/06/09/

[42] Deshmukh SN, MS Basu and PS Reddy (1986). Genetic variability, character association and path analysis of quantitative traits in Virginia bunch varieties of ground nut. Indian Journal of Agriculture Science, 56: 816-821. http://agris.fao.org/agrissearch/search.do?recordID $=$ IN198700 39515

[43] Yadeta B, D Belew, W Gebreselassie and F Marame (2011). Variability, heritability and genetic advance in hot pepper $(C$. annuum L.) genotypes in West Shoa Ethiopia. AmericanEurasian Journal of Agricultural \& Environmental Sciences, $10 \quad$ (4): $587-592$. https://www.idosi.org/aejaes/jaes10(4)/16.pdf

[44] Sreelathakumary I and I Rajamory (2004). Variability, heritability and genetic advance in chili (Capsicum annuum L.). Journal of Tropical Agriculture, 42 (1-2): 35-37. http://jtropag.kau.in/ index.php/ojs2/article/view/112/112

[45] Rosmaina, Syafrudin, Hasrol, F Yanti, Juliyanti and Zulfahmi (2016). Estimation of Variability, Heritability and Genetic Advance Among Local Chili Pepper Genotypes Cultivated in Peat Lands. Bulgarian Journal of Agricultural Science, Agricultural Academy, 22 (3), 431-436. https://journal. agrojournal.org/page/en/ details.php?article_id $=257$

[46] Burton GW, \& DeVane EH (1953). Estimating Heritability in Tall Fescue (Festuca Arundinacea) from Replicated Clonal Material1. Agronomy Journal, 45 (10), 478. DOI: 10.2134/agronj1953.00021962004500100005x.

[47] Hamdi A, AA El-Ghareib, S. A. Shafey and M. A. M. Ibrahim (2013). Genetic variability, heritability, and expected genetic advance for earliness and seed yield from selection in lentil. Ministry of Agriculture, Giza, Egypt, 81 (1): 125-138. https://books.google.com.bd/books?id=VfT6hZHpXPkC\&pg= PA204\&lpg=PA204\&dq

[48] Maiti RK (1979). A study of the microscopic structure of the fiber strands of common Indian bast fibers and its economic implications. Economic Botany, 33 (1), pp. 78-87. https://www.jstor.org/stable/ i389412

[49] Sengupta G and P Palit (2004). Characterization of a Lignified Secondary Phloem Fibre-deficient Mutant of Jute (Corchorus capsularis L.). Annals of Botany, 93: 211-220. DOI: 10.1093/aob/mch029.
[50] Snegireva A, Chernova T, Ageeva M, Lev-Yadun S, Gorshkova $T$ (2015). Intrusive growth of primary and secondary phloem fibers in hemp stem determines fiberbundle formation and structure. AoB PLANTS, 7: plv061; DOI: 10.1093/aobpla/plv061.

[51] Milla, AJ, AR Akanda, SK Biswas and MA Uddin (2018). Determination of Crop Co-efficient Values for Jute (Corchorus olitorius L.). The Agriculturists, 16 (2): 115-122. DOI: http://dx.doi.org/ 10.3329/agric. v16i02.40349

[52] Majumdar S (2002). Prediction of fiber qualities from anatomical studies in jute stem: Part-I prediction of fineness. Indian J. Fiber Textile Res. 27: 248-53. http://nopr.niscair. res.in/bitstream/123456789/22849/1/IJFTR\% 2027(3)\%20248-253.pdf

[53] Pervin N and GKMN Haque (2012). Variability in anatomical characters in relation to fiber content and quality in white jute (Corchorus capsularis L.). International Research Journal of Applied Life Sciences. V-1, Issue-4, Article-6. DOI: 10.1.1.448.1564 \&rep=rep1\&type=pdf

[54] Kumar V, A Prakash and AK Kashyap (2018). Combining ability and heterosis following line $\mathrm{x}$ tester analysis for fiber anatomical characters in cultivated jute. Plant Archives, Vol. 18 No. 2, pp. 2042-2046. http://www.plantarchives.org/1802/2042-2046\%20(4277).pdf

[55] Islam, MR, MM Islam, N Akter, RK Ghosh, Z Al Rafique and AKMS Hossain (2002). Genetic Variability and Performance of Tossa Jute (Corchorus olitorius L.). Pakistan Journal of Biological Sciences, 5: 744-745. DOI:10.3923/pjbs.2002. 744.745.

\section{Biography}

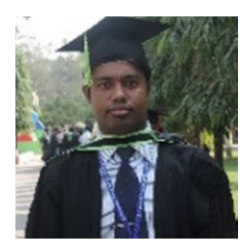

Mukul Md. Mia (19-05-1991; 5 No. Ward, Taluk Sarbananda, Sundarganj, Gaibandha; $25^{\circ} 30^{\prime} 32.1^{\prime \prime} \mathrm{N} \quad 89^{\circ} 28^{\prime} 38.7^{\prime \prime E}$ ), Scientific Officer, Breeding Division, www.bjri.gov.bd, Dhaka, Bangladesh working on Jute (Corchorus spp. L.) breeding to develop biotic-abiotic stress tolerant climate smart high yielding varieties since 19 January, 2017. He is expert on Jute, Rice Breeding to develop HYV. He completed MS (2014) on Genetics and Plant Breeding and B.Sc. Agril. Honours (2012) from www.bau.edu.bd, Mymensingh-2202. He has awarded NST Fellowship (2013-14), Govt. of Bangladesh for Research on Food \& Agriculture: 'Characterization of Rice Genotypes for Nutrient Content'. He also worked as Scientific Officer (Transformed Rice Breeding), Breeding Division, www.brri.gov.bd, collaborated bycollaboration of IRRI, Philippines during April-Nov, 2016. 